\title{
PENGEMBANGAN KURIKULUM BERBASIS KEMAJEMUKAN
}

Moh. Kamilus Zaman

UIN Maulana Malik Ibrahim Malang zamankamilus@gmail.com

\begin{abstract}
Abstrak
Guru agama seharusnya menjadikan peserta didik menjadi yang berperadaban, berbudaya, berakhlak, berkarakter, ala Indonesia. dengan menjunjung tinggi nilai-nilai al-qur'an, dan pancasila, menghargai kemajmukan, suku, agama ras, sesuai dengan ajaran Islam yang dibawa Oleh Nabi Muhammad SAW, yang membangun Kota Yastrib menjadi kota Madinah yang didalamnya juga bermajmuk. Sebagai upaya Pengembangan Kurikulum PAI Berbasis Kemajemukan, disini lembaga harus mencoba mengembangkan dan merekontruksi kembali kurikulum Pemerintah dari yang sentralisasi menjadi Desentralisasi, agar Tujuan Pendidikan Agama Islam di lembaga tersebut tercapai, Untuk merealisasikannya Maka:

1). Pengembangan kurikulum PAl: pengembangan kurikulum Pendidikan Agama Islam (PAI) dapat berarti: (1) kegiatan menghasilkan kurikulum PAl; atau (2) proses yang mengaitkan satu komponen dengan yang lainnya untuk menghasilkan kurikulum PAl yang lebih baik; dan/atau (3) kegiatan penyusunan (desain), pelaksanaan, penilaian dan penyempur-naan kurikulum PAI. 2). LangkahLangkah dalam Pengembangan Kurikulum PAI Berbasis Kemajemukan, dari berbagai Aspek: (1) aspek Tujuan: Menjaga akidah dan ketakwaan peserta didik. 2) Menjadi landasan untuk lebih rajin mempelajari dan mendalami ilmu-ilmu agama. 3) Mendorong peserta didik untuk lebih kritis, kreatif dan inovatif. 4) Menjadi landasan perilaku dalam kehidupan sehari-hari didalam masyarakat. Dengan demikian bukan hanya mengajarkan pengetahuan secara teori semata tetapi juga untuk dipraktekkan
\end{abstract}


atau diamalkan dalam kehidupan sehari-hari (membangun etika sosial). 5) Nasionalis 6) Membentuk Pribadi Muslim (2) Aspek Materi: Memperluas/menambah indikator, Muatan lokal, konten pelajarannya tidak harus sejarah tentang perang dan kesenjangan antara Islam dan non Islam, yang diajarkan karya Tokoh-Tokoh Nusantara. Materi yang disajikan hendaknya lebih bersifat fungsional (3) Aspek Lembaga: Lembaga Pendidikan Agama Islam harus toleran terhadap kemajemukan siswa baik Ras, Suku bahkan Agama.

Kata Kunci : Kurikulum, Kemajemukan

\section{Pendahuluan}

Intoleransi agama tidak dapat dibenarkan, karena Islam yang menggelorakan misi antiperang, antiterorisme, antikekerasan, antipenindasan, antiketerbelakangan, dan anti terhadap segala bentuk pengrusakan di muka bumi seperti Bom Bunuh diri, korupsi, penyalahgunaan kekuasaan, kejahatan kemanusiaan, eksploitasi alam, serta berbagai kemunkaran yang menghancurkan kehidupan. Islam yang secara positif melahirkan keutamaan yang memayungi kemajemukan suku, bangsa, ras, golongan dan kebudayaan umat manusia di muka bumi.

Intoleransi agama sudah menjamur di kantong-kantong lembaga pendidikan baik di lembaga pendidikan formal (Sekolah dasar, SMP dan SMAPerguruan Tinggi), maupun di lembaga no formal (pondok pesantren). Maka sudah barang tentu, sebagai langkah preventif dari ancaman ini, lembaga pendidikan sebagai solusi pamungkas untuk menghentikan praktek InIslam sejati agama yang sangat Tragis itu.

Seperti yang kita ketahui, lembaga pendidikan baik formal/non formal salah satu sentrum dimana proses transfer knowloagde dan transfer value di jawantahkan. Dan apabila dalam satu titik ini sudah diajarkan tentang InIslam sejati agama, maka akan lahirlah generasi-generasi intoleran dan tidak cinta pada bangsanya.

Fakta penelitian yang dilakukan Kemendikbud menunjukkan. Ada potensi inlslam sejati terjadi di sekolah karena ada 8,2 persen yang menolak Ketua OSIS dengan agama yang berbeda. Selain itu, ada pula 23 persen yang merasa nyaman dipimpin oleh seseorang yang satu agama. Memang angka 8,2 ini tidak terlalu besar diabandingkan angka 23, akan tetapi angka ini menjadi warning bagi seorang guru atas kegagalan lembaga pendidikan dalam menanamkan Islam sejati di sekolah. Maka menjadi tugas tersendiri 
bagi sekolah terutama guru pendidikan agama Islam untuk menghilangkan angka kecil yang dinamis itu. Lantas bagaimana yang harus dilakukan oleh guru agama.

Guru agama seharusnya menjadikan peserta didik menjadi yang berperadaban, berbudaya, berakhlak, berkarakter, ala Indonesia. dengan menjunjung tinggi nilai-nilai al-qur'an, dan pancasila, menghargai kemajmukan, suku, agama ras, sesuai dengan ajaran Islam yang dibawa Oleh Nabi Muhammad SAW, yang membangun Kota Yastrib menjadi kota Madinah yang didalamnya juga bermajmuk.

Realitas menunjukkan bahwa kehidupan umat Islam saat ini relatif terbelakang, terpuruk, bahkan tertinggal dari umat-umat yang lain. Kondisi umat Islam yang seperti itu tidaklah terjadi secara tiba-tiba, tetapi melalui proses yang panjang. Umat Islam lebih tertarik kepada ilmu-ilmu tradisional, dengan argument bahwa ilmu itu luas, sedangkan hidup di dunia ini singkat, maka orang Islam harus memprioritaskan ilmu-ilmu agama sebagai kunci kejayaan hidup di akhirat, dan berimbas pada pengesampingan ilmu-ilmu rasional.

Oleh karena itu, pengembangan kurikulum pendidikan Islam berbasis Islam sejati ini harus menekankan pada pengembangan ilmu-ilmu tradisional dan rasional karena ini penting untuk meningkatkan keberhasilan sistem pendidikan Islam secara menyeluruh serta menghilangkan dikotomi antara keduanya.

Sebagai upaya Pengembangan Kurikulum PAI Berbasis Kemajemukan , disini lembaga harus mencoba mengembangkan dan merekontruksi kembali kurikulum Pemerintah dari yang sentralisasi menjadi Desentralisasi, agar Tujuan Pendidikan Agama Islam di lembaga tersebut tercapai. Untuk itu disini penulis mengangkat judul " Pengembangan Kurikulum PAI Berbasis Kemajemukan"

\section{Kurikulum PAI.}

Dalam Undang-undang Sistem Pendidikan Nasional nomor 20 tahun 2003, kurikulum adalah seperangkat rencana dan pengaturan mengenai tujuan, isi, dan bahan pelajaran serta cara yang digunakan sebagai pedoman penyelenggaraan kegiatan pembelajaran untuk mencapai tujuan pendidikan tertentu. ${ }^{1}$

Kurikulum pendidikan agama Islam adalah bahan-bahan, aktivitas, pengalamanan yang mengandung unsur ketauhidan. Kalimat tauhid yang

${ }^{1}$ Undang-undang Republik Indonesia Nomor 14 Tahun 2005 tentang Guru dan Dosen serta Undang-undang Republik Indonesia Nomor 20 Tahun 2003 tentang Sisdiknas (Bandung: Citra Umbara), hlm. 74. 
diperdengarkan pada bayi saat baru lahir merupakan meteri kurikulum pendidikan islam, fungsi azan yang berintikan ketauhidan dalam pendidikan islam sangat penting untuk ditanamkan ke dalam pribadi anak muslim sedini mungkin, dengan harapan mereka senantiasa terbimbing ke suasana dan kondisi yang sejalan dengan hakekat penciptaanya, sebagai pengabdi Allah. ${ }^{2}$

Kurikulum pendidikan agama Islam mencakup rumusan tentang tujuan, materi, metode, dan evaluasi dalam pendidikan agama Islam sebagaimana kurikulum barat.Ajaran ini dirumuskan berdasarkan Al-Qur'an dan Hadits serta akal.Islam sebagai agama yang memiliki tujuan pokok/ materi, metode, dan evaluasi yang jauh sebelum teori barat muncul. ${ }^{3}$

Untuk menjamin efektivitas pengembangan kurikulum dan program pembelajaran, kepala sekolah sebagai pengelola program pengajaran bersama guru-guru harus menjabarkan isi kurikulum secara rinci dan operasional kedalam program tahunan, semester, dan bulanan. Adapun program mingguan atau program satuan pelajaran wajib dikembangkan guru sebelum melakukan kegiatan belajar-mengajar.

Kurikulum pendidikan agama Islam adalah bahan-bahan pendidikan agama berupa kegiatan, pengetahuan dan pengalaman serta nilai atau norma-norma dan sikap yang dengan sengaja dan sistematis diberikan kepada anak didik dalam rangka mencapai tujuan pendidikan agama.Dapat disebutkan, pendidikan agama Islam yaitu alat untuk mencapai tujuan pendidikan agama. Dalam kurikulum pendidikan agama Islam meliputi dua, Pertama, penyesuaian dengan tujuan pendidikan agama; kedua, penyesuaian dengan tingkat usia, tingkat perkembangan kejiwaan anak dan kemampuan anak.

Sebab itu, kurikulum di madrasah dan sekolah umum dibakukan oleh pemerintah, sesuai dengan Surat Keputusan Menteri Dikbud dan Menteri Agama No. 0299/U/1984 dan No 54 Tahun 1984 tentang pengaturan pembukuan kurikulum madrasah dan Sekolah umum. SKB kedua menteri tersebut sebagai tindak lanjut SKB tiga menteri (menteri Agama, menteri P dan K, dan menteri dalam Negeri) tanggal 24 Maret 1975 No. 6 Tahun 1975; No 037/U/1975; dan 36 Tahun $1975 .{ }^{4}$

Ditegaskan pula pada Pasal 6 ayat 1 dan 2 UU No. 28 Tahun 2003 dijelaskan bahwa kurikulum jenis pendidikan umum, kejuruan dan pada

\footnotetext{
${ }^{2}$ Abdullah, Pengembangan Kurikulum Teori dan Praktek (Jogjakarta, Ar-Ruz media 2007), hlm. 60.

3 Sanaki.Hujair, Paradigma pendidikan Islam (membangun masyarakat madani)" (Yogyakarta. Safarina insani prees 2003), hlm. 34.

${ }^{4}$ Zuhairini dan Abdul Ghofir, Metodelogi Pendidikan Agama Islam (Malang: UIN dan UM Press, 2004), hlm. 43.
} 
jenjang pendidikan dasar menengah terdiri atas: kelompok mata pelajaran agama dan akhlak mulia; kelompok mata pelajaran kewarganegaraan dan kepribadian; kelompok mata pelajaran mata pelajaran ilmu pengetahuan dan teknologi; kelompok mata pelajaran estetika; kelompok mata pelajaran jasmani, olah raga dan kesehatan. Sedangkan kurikulum untuk jenis pendidikan keagamaan terdiri dari atas kelompok mata pelajaran yang ditentukan berdasarkan tujuan pendidikan keagamaan. ${ }^{5}$ Adapun Ciri-ciri Kurikulum Pendidikan agama Islam, antara lain:

1. Kurikulum pendidikan Islam harus mengedepankan mata pelajaran akhlak. agama dan akhlak yang bersumber dari Al-Qur'an dan Hadits beserta teladan tokoh-tokoh terdahulu yang sholeh.

2. Harus memperhatikan pengembangan menyeluruh aspek pribadi siswa, yaitu aspek jasmani, akal, dan rohani. Kurikulum Pendidikan Islam memperhatikan keseimbangan antara pribadi dan masyarakat, dunia dan akhirat; keseimbangan yang bersifat relatif karena tidak dapat diukur secara obyektif.

3. Kurikulum pendidikan Islam memperhatikan ketrampilan, yaitu; seni, pahat, kaligrafi, gambar dan sejenisnya. Selain itu pendidikan Jasmani, latihan militer, teknik, ketrampilan, dan bahasa asing.

4. Kurikulum pendidikan Islam melihat aspek kemajemukan kebudayaan. ${ }^{6}$

\section{Lingkup Standar Nasional Pendidikan}

pemerintah menetapkan Delapan Standar Nasional Pendidikan Indonesia yang menjadi pedoman bagi pendidik dan tenaga kependidikan untuk mengembangkan kemampuan dan membentuk watak serta peradaban bangsa yang bermartabat dalam rangka mencerdaskan kehidupan bangsa. Kedelapan lingkup standar nasional pendidikan itu meliputi sebagai berikut:

1. Standar isi Standar isi adalah: Ruang lingkup materi dan tingkat kompetensi yang dituangkan dalam kriteria tentang kompetensi tamatan, kompetensi bahan kajian, kompetensi mata pelajaran, dan silabus pembelajaran yang harus dipenuhi oleh peserta didik pada jenjang dan jenis pendidikan tertentu.

2. Standar proses: standar proses pendidikan berkaitan dengan pelaksanaan pembelajaran, yang berarti dalam standar proses

${ }^{5}$ Undang-Undang Republik Indonesia Nomor 14 Tahun 205 tentang Guru dan Dosen serta UUD republik Indosia Nomer 20 Tahun 2003 tentang Sikdiknas.( Penebit Citra Umbara Bandung), hlm. 172.

${ }^{6}$ Abdullah.Pengembangan Kurikulum.., hlm. 100. 
pendidikan berisi tentang bagaimana seharusnya proses pembelajaran berlangsung.

3. Standar kompetensi lulusan: tandar proses pendidikan diarahkan untuk mencapai standar kompetensi kelulusan.

4. Standar pendidik dan tenaga kependidikan: kriteria pendidikan prajabatan dan kelayakan maupun mental, serta pendidikan dalam jabatan.

5. Standar sarana dan prasarana: adalah standar nasional pendidikan yang berkaitan dengan kriteria minimal tentang ruang belajar, tempat berolahraga, tempat beribadah, perpustakaan, laboratorium, bengkel kerja, tempat bermain, tempat berkreasi dan berekreasi serta sumber belajar lain, yang diperlukan untuk menunjang proses pembelajaran, termasuk penggunaan teknologi informasi dan komunikasi.

6. Standar pengelolaan: adalah standar nasional pendidikan yang berkaitan dengan perencanaan, pelaksanaan, dan pengawasan kegiatan pendidikan pada tingkat satuan pendidikan, kabupaten/kota, provinsi, atau nasional agar tercapai efisiensi dan efektivitas penyelenggaraan pendidikan.

7. Standar pembiayaan: adalah standar yang mengatur komponen dan besarnya biaya operasi satuan pendidikan yang berlaku selama satu tahun.

8. Standar penilaian pendidikan: adalah standar nasional pendidikan yang berkaitan dengan mekanisme, prosedur, dan instrumen penilaian hasil belajar peserta didik. ${ }^{7}$

\section{Pendidikan Agama Islam}

Pendidikan dalam pengertian yang sederhana dan umum adalah sebagai usaha manusia untuk menumbuhkan dan mengembangkan potensipotensi bawaan, baik jasmani maupun rohani sesuai dengan nilai-nilai yang ada dalam masyarakat dan kebudayaan. ${ }^{8}$ Sedangkan menurut Freeman Butt pendidikan adalah kegiatan menerima dan memberikan pengetahuan sehingga kebudayaan dapat diteruskan dari generasi ke generasi berikutnya. ${ }^{9}$

Di samping itu, pendidikan dapat diartikan dengan proses transformasi ilmu pengetahuan dari pendidik kepada peserta didik, agar ia memiliki sikap

${ }^{7}$ Undang-Undang R.I Nomor 14 tahun 2005 dan Peraturan menteri Pendidikan Nasional RI Nomor 11 tahun 2011 Tentang Guru dan Dosen. (Bandung:Citra Umbara. 2012), hlm. 59.

${ }^{8}$ Moh. Kamilus Zaman dan Moh Soleh, Metode Pendidikan dalam Al-Qur'an; Analisis Tafsir Surat An-Nahl ayat 125,( Blora : Probi Media, 2016), hlm. 2.

${ }_{9}^{9}$ M. Djumransjah, Filsafat Pendidikan (Malang : Bayumedia Publishing, cet. I, 2006), hlm. 116 
dan semangat yang tinggi dalam memahami dan menyadari kehidupannya, sehingga terbentuk ketakwaan, budi pekerti dan pribadi yang luhur. ${ }^{10}$

Menurut Ahmad D. Marimba, sebagaimana dikutip oleh Suwarno, pendidikan adalah bimbingan atau pimpinan secara sadar oleh si pendidik terhadap perkembangan jasmani dan rohani si terdidik menuju terbentuknya kepribadian yang utama. ${ }^{11}$ Selanjutnya menurut Mulyahardjar pendidikan ${ }^{12}$ adalah segala pengaruh yang diupayakan sekolah terhadap anak dan remaja yang diserahkan kepadanya agar mempunyai kemampuan. ${ }^{13}$

Pendidikan juga dapat diartikan bimbingan secara sadar oleh pendidik terhadap perkembangan jasmani dan rohani peserta didik menuju terbentuknya kepribadian yang utama. ${ }^{14}$ Dari pengertian di atas dapat digaribawahi, bahwa dalam pendidikan adalah: sebuah proses dan transformasi pengetahuan dari pendidik terhadap peserta didik. Sehingga terjadi suatu perubahan ke arah yang positif pada peserta didik, baik dalam aspek kognitif, afektif, maupun psikomutorik. ${ }^{15}$

Dalam term yang serupa (menurut penulis) dengan Pendidikan Agama Islam adalah Pendidikan Islam. Al-Syaibani mengartikannya sebagai "usaha pendidikan untuk mencapainya, baik pada tingkah laku individu dan pada kehidupan pribadinya atau pada kehidupan masyarakat dan pada kehidupan alam sekitar pada proses kependidika". ${ }^{16}$

Sedang Al- Nahlawi memberikan pengertian Pendidikan Islam adalah "sebagai pengaturan pribadi dan masyarakat sehingga dapat memeluk Islam

${ }^{10}$ Abdul Mujib dan Jusuf Muzakkair, Ilmu Pendidikan Islam, (Jakarta: Kencana Prenada Media, 2006), hlm.12-13

${ }^{11}$ Suwarno, Pengantar Umum Pendidikan, (Jakarta: Aksara Baru, 1985), hlm.2

12 Dalam bahasa arab disebut "At-Tarbiyah" (mengembangkan, menumbuhkan, menyuburkan) berakar satu dengan kata " Rabb" (Tuhan Yang Maha memelihara). Hal ini mengindikasikan bahwa pendidikan adalah sebuah nilai-nilai luhur yang tidak dapat dipisahkan dari, serta dipilah-pilah dalam kehidupan manusia. Terpisahnya pendidikan dan terpilah-pilahnya bagian-bagiannya dalam kehidupan manusia berarti pula terjadi disintegrasi dalam kehidupan manusia, yang konsekwensinya melahirkan ketidakharmonisan dalam kehidupannya. M. Syamsi Ali, Dai Muda di New York City, (Jakarta: Gema Insani, 2007), hlm. 157.

13 Mulyahardjar, redja, Pengantar Pendidikan,(Jakarta: PT. Raja Grafindo Persada, 2001), hlm.. 3.

14 Zuhairini dan Abdul Ghafir, Metodologi Pembelajaran Pendidikan Agama Islam, (Malang: UM PRESS, Cetakan Pertama, 2004) hlm. 1

15 Kamilus Zaman dan Moh Soleh, Metode Pendidikan dalam Al-Qur'an.., hlm.2

16 Al-Syaibany, Falsafah al-Tarbiyyah al- Islamiyyah, Alih Bahasa: Hasan Langgulung, FalsafahPendidikan Islam, (Jakarta: Bulan Bintang, 1979), cet-1, hlm. 399. 
secara logis dan sesuai secara keseluruhan baik dalam kehidupan individu maupun masyarakat (kolektif)" ${ }^{17} \mathrm{Hal}$ yang senada juga disampaikan Muhammad Fadhil al-Jamaly; mendefinisikan pendidikan Islam sebagai upaya mengembangkan, mendorong serta mengajak peserta didik hidup lebih dinamis dengan berdasarkan nilai-nilai yang tinggi dan kehidupan yang mulia. Dengan proses tersebut, diharapkan akan terbentuk pribadi peserta didik yang lebih sempurna, baik yang berkaitan dengan potensi akal, perasaan, maupun perbuatannya. ${ }^{18}$

Ahmad D. Marimba; mengemukakan bahwa pendidikan Islam adalah bimbingan atau pimpinan secara sadar oleh pendidik terhadap perkembangan jasmani dan rohani peserta didik menuju terbentuknya kepribadiannya yang utama (insan kamil). ${ }^{19}$ Juga Ahmad Tafsir; mendefinisikan pendidikan Islam adalah bimbingan yang diberikan oleh seseorang kepada seseorang agar ia berkembang secara maksimal sesuai dengan ajaran Islam. ${ }^{20}$

Pendidikan Agama Islam dan beberapa definisi pendidikan Islam di atas, terdapat kemiripan makna yaitu keduanya sama-sama mengandung arti pertama, adanya usaha dan proses penanaman sesuatu (pendidikan) secara kuntinue. Kedua, adanya hubungan timbal balik antara orang pertama (orang dewasa, guru, pendidik) kepada orang kedua, yaitu peserta dan anak didik. dan ketiga adalah Akhlakul Karimah sebagai tujuan akhir. Namun tidak kalah pentingnya dari aspek epistemologi bahwa pembinaan dan pengoptimalan potensi; penanaman nilai-nilai Islam dalam jiwa, rasa, dan pikir; serta keserasian dan keseimbangan. ${ }^{21}$

\section{Pengembangan kurikulum PAI}

Pengembangan kurikulum Pendidikan Agama Islam (PAI) dapat berarti: kegiatan menghasilkan kurikulum PAl; atau proses yang mengaitkan satu komponen dengan yang lainnya untuk menghasilkan kurikulum PAI yang lebih baik; dan/atau kegiatan penyusunan (desain), pelaksanaan, penilaian dan penyempurnaan kurikulum PAl.

Dalam realitas sejarahnya, pengembangan kurikulum PAI tersebut ternyata mengalami perubahan-perubahan paradigma, walaupun dalam

17 Abdurrahman al-Nahlawi, Ushul al-Tarbiyah al-Islamiyah wa Asalibiha, (Damaskus: Dar al-Fikr, 1979), hlm. 20

${ }^{18} \mathrm{Al}$-Rasyidin dan H. Samsul Nizar, Filsafat Pendidikan Islam, (Jakarta: Ciputat Press, 1995), hlm. 31- 32

${ }^{19}$ Ibid., hlm. 32

20 Ahmad Tafsir, Ilmu Pendidikan Dalam Perspektif Islam, (Bandung: PT. Remaja Rosdakarya, 1994), cet-2, hlm. 32

${ }^{21} \mathrm{http} / /$ Moh. kamilus zaman, blogspot, diakses pada tanggal 25-12-2017. 
beberapa hal tertentu paradigma sebelumnya masih tetap dipertahankan hingga sekarang. Hal ini dapat dicermati dari fenomena berikut: perubahan dari tekanan pada daya hafalan dan daya ingatan tentang teks-teks dari ajaran-ajaran agama Islam, serta disiplin mental spiritual sebagaimana pengaruh dari Timur Tengah, kepada pemahaman tujuan, makna dan motivasi beragama Islam untuk mencapai tujuan pembelajaran PAl; perubahan cara berpikir tekstual, normatif dan absolutis kepada cara berpikir historis, empiris dan kontekstual dalam memahami dan menjelaskan ajaranajaran dan nilai-nilai agama Islam; perubahan dari tekanan pada produk atau hasil pemikiran keagamaan Islam dari para pendahulunya kepada proses atau metodologinya sehingga menghasilkan produk tersebut; dan perubahan dari pola pengembangan kurikulum PAI yang hanya mengandalkan pada para pakar dalam memilih dan menyusun isi kurikulum PAI ke arah keterlibatan yang luas dari para pakar, guru, peserta didik, masyarakat untuk mengidentifikasi tujuan PAI dan cara-cara mencapainya. ${ }^{22}$ Sedangkan Proses Pengembangan Kurikulum sebaigai berikut:

Pertama, Perencanaan, Ide Asal dari : 1) Visi (pernyataan tentang harapan yang ingin dicapai oleh suatu lembaga pendidikan dalam jangka panjang) 2) Kebutuhan pengguna (pelajar, masyarakat,pengguna lulusan) dan studi lanjut 3) Hasil evaluasi kurikulum sebelumnya dan tuntutan perkembangan iptek juga zaman. 4) Pandangan para Ahli pendidikan 5) Era globalisasi. => 5 ide diatas akan dievaluasi untuk di kembangkan menjadi Program berupa Dokumen/Berkas yang berisi : Informasi dan jenis dokumen, Format silabus dan komponen kurikulum yang harus dikembangkan.

Kedua, Implementasi, Melakukan sosialisasi dan pengembangan Program berupa pengembangan kurikulum dalam bentuk RPP atau SAP (Satuan Acara Pembelajaran), proses pembelajaran di dalam dan diluar kelas, serta evaluasi pembelajaran untuk mengetahui tingkat efektivitas dan efisiensi Program tersebut.

Ketiga, Evaluasi, Dari evaluasi ini akan di peroleh feedback (umpan balik) yang akan digunakan dalam penyempurnaan kurikulum berikutnya. ${ }^{23}$

Menurut penulis Kurikulum dikatakan suatu kurikulum, jika:

22 Muhaimin, Wacana Pengembangan Pendidikan Islam, (Yogyakarta: Pustaka Pelajar, 2004). hlm. 10-11.

${ }^{23}$ Muhaimin, Pengambangan Kurikulum Pendidikan Agama Islam ; di Sekolah, Madrasah dan Perguruan Tinggi, (PT.Raja Grafindo Persada, Jakarta : 2012), hlm. 1213. 


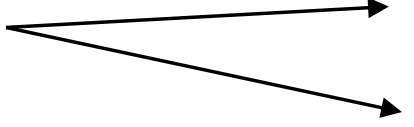

TRANSFER OF VALUE

Kedua hal tersebut dapat ditempuh melalui rekayasa kurikulum, yang dalam hal ini merupakan bias implementasi dari kurikulum KTSP atau K 13, yang dikatakan sebagai kurikulum yang diterapkan sesuai dengan otonomi lembaga masing-masing. Dan menurut Penulis Lembaga Pendidikan Agama Islam harus berani dalam merekayasa-merekayasa suatu kurikulum. Adapun pengembangan kurikulum silihat dari berbagai Aspek antara lain:

Pertama, Aspek Materi: Diantara prinsip pengembangan kurikulum ada prinsip relevansi yang ahrus menjadi pertimbangan bagi penentuan suatu materi. Agar materi yang diberikan bermanfaat bagi kehidupan anak didik, hendaknya materi tersebut harus sesuai dengan tuntutan zaman, kesempurnaan jiwa anak didik tanpa melupakan esensi ajaran Islam itu sendiri.

Kedua, Aspek Tujuan: Dalam prinsip pengembangan kurikulum hal ini sangat berkaitan dengan prinsip efektifitas. Dengan semakin banyaknya tujuan yang harus dicapai, akan mendorong efektifitas proses yang akan dilaksanakan. Sebagai suatu rancangan, tentu ada rencana yang dapat tercapai. Dan sebaiknya tujuan yang akan dicapai harus jelas dan memang benar-benar sesuai dengan segala komponen yang berpengaruh terhadap pendidikan itu sendiri. Jangan sampai apa yang diajarkan dan proses pelaksanaannya sangat berbeda dengan tujuan yang diharapkan.

Ketiga, Aspek Lembaga: Banyak orang beranggapan bahwa mengelola lembaga pendidikan agama tidak perlu mendapat perhatian dan penanganan khusus. Karena out-put-nya kurang dapat diandalkan untuk berkompetensi dalam masyarakat jika dibanding out-put lembaga pendidikan lain. Secara administratif, lembaga pendidikan Islam yang benar-benar menerapkan manajemen pendidikan dengan baik sangat jarang sekali. Salah satu hal yang sangat berkaitan dengan lembaga pendidikan adalah lingkungan pendidikan yang menjadi salah satu sarana seorang anak dapat memperoleh pendidikan dengan baik. ${ }^{24}$

Melihat pendapat Armai Arief, dalam buku Pengantar IImu dan Metodologi Pendidikan Islam, diatas maka penulis berusha mengembangkan Kurikulum Dari Berbagai Aspek, Materi, tujuan dan lembaga, sebagai berikut:

${ }^{24}$ Armai Arief, Pengantar IImu dan Metodologi Pendidikan Islam, (Jakarta: Ciputat Pers, 2002), Cet I, hIm 35 


\section{Pengembangan Kurikulum PAI Berbasis kemajemukan, dari aspek Materi}

Aspek Materi: Pada pendidikan madrasah mata pelajaran agama Islam dibagi kedalam beberapa sub mata pelajaran, yaitu: Al-Qur'an-hadits, Aqidah Akhlak, fiqih, sejarah (kebudayaan) Islam, dan bahasa arab. Sehinggga porsi mata pelajaran agama Islam lebih bayak. Sementara pada pendidikan non madrasah, mata pelajaran non Islam digabung menjadi satu, dan porsinya hanya 2 jam per-minggu. Namun, didalamnya, pada dasarnya juga meliputi Al-Qur'an-Hadits, keimanan (aqidah), akhlak, ibadah-syariah-muamalah (fiqih), (dan sejarah kebudayaan) Islam. ${ }^{25}$ Terkait dengan materi disini penulis memberikan terobosan untuk menjawab dari tuntutan zaman, diantaranya memperluas indikator, penguatan muatan lokal, paradigma isi konten materi, penguatan materi sesuai Islam nusantara, materi yang disampaikan bersifat fungsional.

Memperluas/menambah indikator, menyeimbangkan PAI melalui kegiatan teoritis dan praktis berupa kegiata-kegiatan keagamaan dan membuat kurikulum baru berupa mata pelajaran ASWAJA/ke-NU-an keislaman dan mata pelajaran lainnya. dalam rangka untuk mencapai Tujuan Pendidikan Nasional Indonesia, dalam Memperluas/menambah indikator tidak terlepas dari Tujuan lembaga tersebut, "agar tidak terkesan Materi atau mata kuliah eceran" yang sekedar memasukkan mata pelajaran tanpa melihat kebutuhan peserta didik atau tujuan dari lembaga tersebut.

Muatan lokal dalam penyusunan materi-materinya didasarkan pada kejadian-kejadian aktual yang terjadi masyarakat sekitar dan nasional. Selain itu, mulok PAI juga dapat berupa kegiatan baca tulis al Qur'an yang dapat dibina langsung oleh guru PAI atau dengan mendatangkan guru privat.

Konten pelajarannya tidak harus sejarah tentang perang dan kesenjangan antara Islam dan non Islam, akan tetapi bagaimana Lembaga Pendidikan Islam mampu menghadirkan konten yang utuh dalam pembelajaran Islam, semisal bagaimana etika Nabi Muhammad menyikapi perbedaan baik yang bersifat agama, soisal, Politik dan budaya.

Muatan materi tidak hanya Mengkaji fiqih, Tasawwuf dan Al-Qur'an atau Tokoh-tokoh akademisi dari "non Nusantara" tetapi juga mengajarkan Kitab-kitab, Buku-Buku, karya Nusantara. Seperti karya K.H. Hasyim Asyari, K.H. Ahmad Dahlan. Prof Quraisy Sihab dalam ke agamaannya. dan Para Tokoh akademisi seperti Prof Ibrahim bafadol, Prof Muhaimin, Prof Imam Suprayogo. Agar Peserta didik, ikut bangga dan termotivasi untuk mengembangkan Pendidikan Islam Ala Nusantara, dan tercapainya Tujuan Pendidikan secara Kaffah (Nasional).

${ }^{25}$ Muhaimin. Wacana Pengembangan Pendidikan Islam.., HIm. 177. 
Materi yang disajikan hendaknya lebih bersifat fungsional, artinya materi pelajaran harus langsung dapat diterapkan oleh siswa. Tidak harus berbicara terlalu lama mengenai ekspansi dalam merebut kekuasaan, (Ski), tetapi lebih diarahkan pada etos kerja dan etos akademik dan ilmiah yang harus dilakukan oleh siswa, agar bisa berhasil sebagaimana tokoh dalam sejarah Islam.

\section{Pengembangan Kurikulum PAI Berbasis kemajemukan, dari aspek Tujuan}

Aspek Tujuan, dalam prinsip pengembangan kurikulum hal ini sangat berkaitan dengan prinsip efektifitas. Dengan semakin banyaknya tujuan yang harus dicapai, akan mendorong efektifitas proses yang akan dilaksanakan. Sebagai suatu rancangan, tentu ada rencana yang dapat tercapai. Dan sebaiknya tujuan yang akan dicapai harus jelas dan memang benar-benar sesuai dengan segala komponen yang berpengaruh terhadap pendidikan itu sendiri. Jangan sampai apa yang diajarkan dan proses pelaksanaannya sangat berbeda dengan tujuan yang diharapkan. Tujuan tersebut tetap berorientasi pada tujuan penyebutan nasional yang terdapat dalam UU No. 20 tahun 2003. Selanjutnya tujuan umum PAI diatas dijabarkan pada tujuan masingmasing lembaga pendidikan sesuai dengan jenjang pendidikan yang ada. Selain itu, pendidikan agama Islam sebagai sebuah program pembelajaran yang diarahkan untuk:

a. Menjaga akidah dan ketakwaan peserta didik

b. Menjadi landasan untuk lebih rajin mempelajari dan mendalami ilmuilmu agama

c. Mendorong peserta didik untuk lebih kritis, kreatif dan inovatif

d. Menjadi landasan perilaku dalam kehidupan sehari-hari didalam masyarakat. Dengan demikian bukan hanya mengajarkan pengetahuan secara teori semata tetapi juga untuk dipraktekkan atau diamalkan dalam kehidupan sehari-hari (membangun etika sosial). ${ }^{26}$

Terkait dengan tujuan Pengembangan Kurikulum PAI Berbasis Islam sejati disini penulis memberikan terobosan baru untuk menjawab dari tuntutan dan kebutuhan zaman diantaranya:

a. Nasionalis: Untuk mengejewantahkan Pengembangan Kurikulum PAI Berbasis Islam sejati dalam aktifitas keseharaiannya: Lembaga juga harus mampu menciptakan suasana yang dapat mendidik Peserta didik tentang tolerasnsi dan cinta tanah air. Seperti upacara bendara, dan aktifitas Kebangsaan lainnya, karena Tujuan dari pendidikan Agama

26 Hamdan, Pengembangan dan Pembinanaan Kurikulum (Teori dan Praktek Kurikulum PAl), (Banjarmasin: 2009), hlm.40 
Islam selain dari memperkokoh dan menjalankan Aqidah, syari'ah. Dan Akhlak. juga harus bisa menanamkan kecintaan tanah air "Hubbul Wathon Minal Iman"

b. Membentuk Pribadi Muslim (Akhlakul karimah) diawali dengan cara berbusananya ala Nusantara bukan busana barat (You cansee) apalagi busana arab (bercadar, celana cingkrang). dan lain-lain.

\section{Pengembangan Kurikulum PAI Berbasis kemajemukan, dari aspek Lembaga}

Aspek Lembaga, banyak orang beranggapan bahwa mengelola lembaga pendidikan agama tidak perlu mendapat perhatian dan penanganan khusus. Karena out-put-nya kurang dapat diandalkan untuk berkompetensi dalam masyarakat jika dibanding out-put lembaga pendidikan lain. Secara administratif, lembaga pendidikan Islam yang benar-benar menerapkan manajemen pendidikan dengan baik sangat jarang sekali. Salah satu hal yang sangat berkaitan dengan lembaga pendidikan adalah lingkungan pendidikan yang menjadi salah satu sarana seorang anak dapat memperoleh pendidikan dengan baik. ${ }^{27}$

Terkait dengan Lembaga pendikan formal penulis tertarik yang dibangun oleh ibukota Jerman, Berlin. Satu Rumah Tiga Agama yang Berkumpul di Bawah Satu Atap Tidak lama lagi, bakal menyambut sebuah rumah ibadah unik, yang menyatukan tiga agama Ibrahim, yakni Islam, Kristen dan Yahudi. Rencananya The House of One akan memiliki ruang terpisah untuk ketiga agama, dan beberapa ruang umum untuk para pemeluk buat saling bersosialiasi.

Berangkat dari itu, penulis ingin menawarkan sebuah model kurikulum keagamaan yang berbasis Islam sejati, harapannya model ini mampu diajarkan kepada peserta didik ditingkatan sekolah dasar dan menengah atau sederajat. Alasan mendasar yang menjadi prioritas penulis adalah, kabar inlslam sejati itu sudah bisa diakses oleh generasi muda bangsa lewat apapun, terlebih oleh media. sehingga yang terjadi ajaran membenci pada kelompok yang berbeda dengan ajarannya sudah mulai ditampilkan sejak usia itu. Lantas kita bisa apa, untuk mengantisipasi adanya sikap itu. Model dibawah ini salah satu rekomendasi yang seharusnya dilakukan oleh kementian agama dan kementian pendidikan dan kebudayaan.

27 Armai Arief, Pengantar IImu dan Metodologi Pendidikan Islam, (Jakarta: Ciputat Pers, 2002), hlm.35. 


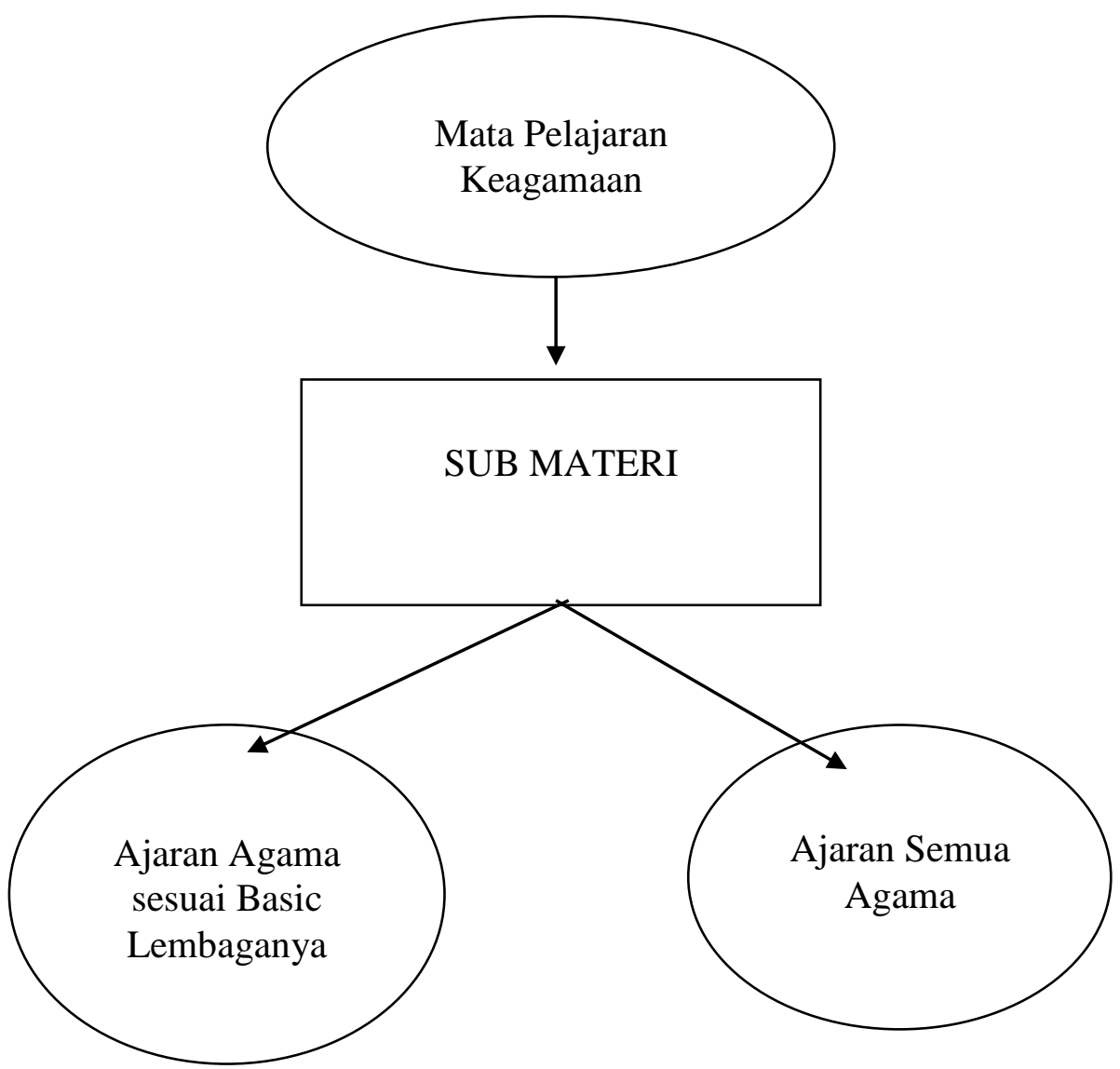

Gambar diatas, adalah bagaimana kementrian agama dan kementrian pendidikan dan kebudayaan dalam rangka membangun pradigma baru tentang Islam sejati didalam mata pelajaran keagamaan. Namun yang menjadi titik tekan dalam model ini adalah prosentase konten. Artinya, ketika sekolahnya itu mempunyai basic Islam, maka prosentase kontennya, 70\% tentang Islam sejati dalam Islam, dan $30 \%$ lagi konten materi agama selain Islam (hanya sebatas pengenalan), hal ini berlaku sebaliknya. Sehingga kedepanya henerasi muda bangsa Indonesia ini tidak ada yang mempunyai sikap sepertihalnya kaum classical falasiy (dikit-dikit haram, dikit-dikit neraka). Karena kemajmukan Indonesia ini akan hancur oleh generasi yang mempunyai sikap seperti itu.

Langkah diatas tentunya diperlukan pembacaan secara inten anatar pemuka agama yang ada di Indonesia, yang pada akhirnya akan ada sajian buku ajaran keagamaan yang ideal sesuai permasalahan bangsa. Jangan sampai kaum radikalis merongrong kedaulatan bangsa ini. 


\section{Penutup}

Pengembangan kurikulum PAl: pengembangan kurikulum Pendidikan Agama Islam (PAI) dapat berarti: (1) kegiatan menghasilkan kurikulum PAl; atau (2) proses yang mengaitkan satu komponen dengan yang lainnya untuk menghasilkan kurikulum PAI yang lebih baik; dan/atau (3) kegiatan penyusunan (desain), pelaksanaan, penilaian dan penyempurnaan kurikulum PAI.

Langkah-Langkah dalam Pengembangan Kurikulum PAI Berbasis Kemajemukan, dari berbagai Aspek: (1) aspek Tujuan: Menjaga akidah dan ketakwaan peserta didik. 2) Menjadi landasan untuk lebih rajin mempelajari dan mendalami ilmu-ilmu agama. 3) Mendorong peserta didik untuk lebih kritis, kreatif dan inovatif. 4) Menjadi landasan perilaku dalam kehidupan sehari-hari didalam masyarakat. Dengan demikian bukan hanya mengajarkan pengetahuan secara teori semata tetapi juga untuk dipraktekkan atau diamalkan dalam kehidupan sehari-hari (membangun etika sosial). 5) Nasionalis 6) Membentuk Pribadi Muslim (2) Aspek Materi: Memperluas/menambah indikator, Muatan lokal, konten pelajarannya tidak harus sejarah tentang perang dan kesenjangan antara Islam dan non Islam, yang diajarkan karya Tokoh-Tokoh Nusantara. Materi yang disajikan hendaknya lebih bersifat fungsional (3) Aspek Lembaga: Lembaga Pendidikan Agama Islam harus toleran terhadap kemajemukan siswa baik Ras, Suku bahkan Agama.

\section{Daftar Rujukan}

Abdullah, Pengembangan Kurikulum Teori dan Praktek, Jogjakarta: Ar-Ruz media, 2007.

Abdurrahman al-Nahlawi, Ushul al-Tarbiyah al-Islamiyah wa Asalibiha, Damaskus: Dar al-Fikr, 1979.

Ahmad Tafsir, Ilmu Pendidikan Dalam Perspektif Islam, Bandung: Remaja Rosdakarya, 1994.

Al-Rasyidin dan H. Samsul Nizar, Filsafat Pendidikan Islam, Jakarta: Ciputat Press, 1995.

Al-Syaibany, Falsafah al-Tarbiyyah al- Islamiyyah, Terj. Hasan Langgulung, FalsafahPendidikan Islam, Jakarta: Bulan Bintang, 1979, cet-1.

Armai Arief, Pengantar IImu dan Metodologi Pendidikan Islam, Jakarta: Ciputat Pers, 2002.

Arief, Armai, Pengantar IImu dan Metodologi Pendidikan Islam, Jakarta: Ciputat Pers, 2002, Cet I.

Arifin, Zainal, Pengembangan Manajemen Mutu Kurikulum Pendidikan Islam, Yogyakarta: Diva Press, 2012. 
Hamdan, Pengembangan dan Pembinanaan Kurikulum ; Teori dan Praktek Kurikulum PAI, Banjarmasin : 2009.

http// Moh. kamilus zaman, blogspot, diakses pada tanggal 25-12-2017.

Hujair, Sanaki, Paradigma pendidikan Islam; membangun masyarakat madani, Yogyakarta : Safarina Insani Prees, 2003.

Kamilus Zaman, Moh dan Moh Soleh, Metode Pendidikan dalam Al-Qur'an : Analisis Tafsir Surat An-Nahl ayat 125, Blora : Probi Media, 2016.

M. Djumransjah, Filsafat Pendidikan, Malang : Bayumedia Publishing, cet. 1, 2006

M. Syamsi Ali, Dai Muda di New York City, Jakarta: Gema Insani, 2007.

Muhaimin, Pengambangan Kurikulum Pendidikan Agama Islam ; di Sekolah, Madrasah dan Perguruan Tinggi, Jakarta : Raja Grafindo Persada, 2012.

Muhaimin, Wacana Pengembangan Pendidikan Islam, Yogyakarta: Pustaka Pelajar, 2004.

Mujib, Abdul dan Jusuf Muzakkair, IImu Pendidikan Islam, Jakarta: Kencana Prenada Media, 2006.

Mulyahardjar, redja, Pengantar Pendidikan, Jakarta: Raja Grafindo Persada, 2001.

Suwarno, Pengantar Umum Pendidikan, Jakarta: Aksara Baru, 1985.

Undang-undang Republik Indonesia Nomor 14 Tahun 2005 tentang Guru dan Dosen serta Undang-undang Republik Indonesia Nomor 20 Tahun 2003 tentang Sisdiknas Bandung: Citra Umbara.

Zuhairini dan Abdul Ghafir, Metodologi Pembelajaran Pendidikan Agama Islam, Malang: UM PRESS, Cet. 1, 2004. 